\title{
PROGRAM PENDIDIKAN SEKS UNTUK MENINGKATKAN PROTEKSI DIRI DARI EKSPLOITASI SEKSUAL PADA ANAK USIA DINI
}

\author{
Zarina Akbar \& Felianti Mudzdaliffah \\ e-mail: zarinaakbar@yahoo.com \\ FIP Universitas Negeri Jakarta
}

\begin{abstract}
Abstrak: Terjadinya kekerasan seksual pada diri anak dapat disebabkan karena anak belum mendapat pendidikan seks. Oleh karena itu, perlu dilaksanakan pendidikan seks untuk anak dan diteliti sejauh mana pendidikan itu dapat meningkatkan proteksi dirinya dari eksploitasi seksual. Penelitian ini bertujuan untuk mengetahui kemampuan proteksi seksual pada anak dari eksploitasi seksual antara sebelum dan sesudah mendapatkan program pendidikan seksual. Penelitian yang dilakukan di Taman Kanak-Kanak (TK) Ar-Rahman Kuningan Jakarta Selatan pada tanggal 23 November dan 28-30 November 2011, menggunakan metode kuantitatif kuasi eksperimen. Hasil analisis antara kelompok eksperimen yang mendapatkan perlakuan pada pengukuran sebelum (pre-test) dan sesudah perlakuan (post-test) menunjukkan perbedaan yang signifikan pada kelompok eksperimen. Berdasarkan hasil analisis tersebut dapat disimpulkan ada perbedaan proteksi diri yang signifikan pada anak usia dini antara sebelum dan sesudah mendapatkan program pendidikan seksual. Dengan demikian, penelitian ini menyarankan program pendidikan seks ini yang merupakan program preventif psikologis, dapat diperkenalkan pada anak sejak dini dalam mengatasi kecenderungan terjadinya perilaku eksploitasi seksual pada anak.
\end{abstract}

Kata kunci : pendidikan seks, proteksi diri anak, eksploitasi seksual

\section{SEX EDUCATION PROGRAM FOR SELF-PROTECTION FROM SEXUAL EXPLOITATION OF EARLY-AGED CHILDREN}

\begin{abstract}
Sexual violence against the children often occurs as they have not got sex education. Therefore, sex education should be provided to the early-age children and a research is conducted to find out the result. This research aims at knowing the children's ability to protect themselves from sexual violance. The research conducted at Ar-Rachman Kindergarten, South Jakarta in November 2011 employed quantitative quasi-experiment. The analysis indicates significant difference in the score between pre-test and post-test of the experiment group. Based on the finding, the research concludes that there is a significant difference in self protection ability for the student having achieved sex education program compared to those who have not. The research recommend sex education should be provided for early-aged children to minimize sexual violence.
\end{abstract}

Keywords: sex education, self-protection, sexual excploitation.

\section{PENDAHULUAN}

Fenomena kasus pelecehan dan kekerasan seksual pada anak di Indonesia akhir-akhir ini semakin meningkat. Hal ini dapat dilihat berdasarkan data dari Pusat Krisis Terpadu (PKT) RSCM Jakarta yang menyebutkan, bahwa pada bulan Juni tahun 2000 sampai dengan bulan Juli tahun 2005 telah terjadi 1200 kasus kekerasan seksual pada anak. Kasus pencabulan terhadap anak laki-laki sebanyak sebanyak 68 kasus, selebihnya adalah anak perempuan. Pada periode Januari-Mei 2008 telah terjadi 298 kasus yang dilaporkan PKT RSCM, di antaranya: 15 kasus pemerkosaan, 113 kasus KDRT, 75 kasus pemerkosaan anak perempuan, 42 kasus kekerasan seksual lainnya pada anak perempuan, 21 kasus kekerasan seksual pada anak laki-laki, dan kasus kekerasan lainnya. Rata-rata ada dua anak yang menjadi korban kekerasan seksual setiap harinya (www.antaranews.com).

Data Komisi Nasional Perlindungan Anak Indonesia (KPAI) sejak awal 2010 hingga Juli 2010 menunjukkan peningkatan pengaduan kekerasan kepada anak. Jika sepanjang tahun 2010 hanya ada 600 pengaduan, tujuh bulan pertama 2011 sudah ada 1085 kasus pengaduan, di antaranya 250 pengaduan kekerasan pada anak atau sekitar $23 \%$ dari total pengaduan. Sepanjang tahun 2009, persentase kekerasan pada anak sebesar $15 \%$. KPAI juga mendapati usia korban anak yang menjadi korban kekerasan seksual juga semakin muda (www.republika.com ).

Data di Polda Metro Jaya sampai akhir bulan Juni tahun 2003 menunjukkan 54 kasus pemerkosaan pada anak. Data yang diperoleh dari Polda Jabar dalam kurun waktu 6 bulan (Oktober 2001 - Maret 2002) telah 
terjadi 116 kasus kekerasan seksual kepada anak-anak. Kasus-kasus itu meliputi 57 kasus pemerkosaan, 25 kasus pencabulan, 9 kasus disodomi, 1 kasus dibawa lari dan disetubuhi, 6 kasus dilacurkan, 9 kasus pelecehan seksual, dan 9 kasus usaha pemerkosaan (www. antaranews.com ).

Dari beberapa data dan kasus kekerasan seksual anak yang terjadi, dikarenakan anak tidak tahu dan tidak menyadari bahwa perlakuan orang dewasa yang menyentuh bagian pribadi adalah perlakuan yang salah. Hal ini terjadi karena anak-anak belum pernah diajarkan mengenal bagian tubuhnya terutama alat kelaminnya. Anak tidak dikenalkan bagian pribadi mana yang boleh dan tidak boleh disentuh. Anak tidak mengetahui mana sentuhan yang aman dan tidak aman, serta tidak mengetahui bagaimana mempertahankan diri bila mengalami perlakuan tersebut (Sumartono \& Intasari, 2008). Hal ini tercakup dalam pendidikan seks yang seharusnya dijelaskan oleh orangtua dan sekolah. Kenyataannya pendidikan seks masih belum diterapkan di rumah dan di sekolah karena banyak yang beranggapan bahwa pendidikan seks sangat tabu dibicarakan pada anak usia dini.

Pendidikan seks sudah seharusnya diberikan sejak usia dini untuk mencegah permasalahan seksual yang semakin berkembang. Penelitian yang dilakukan oleh Surtiretna (dalam Kurniati dkk., 2005) menyatakan, pendidikan seks harus dimulai sedini mungkin mulai masa kanak-kanak dan terus berlangsung hingga usia remaja. Dalam ajaran agama Islam, pendidikan seks tidak dapat dipisahkan dari agama dan bahkan sepenuhnya harus dibangun di atas landasan agama. Dengan demikian, diharapkan akan terbentuk individu yang bertanggung jawab. Pemberian pendidikan seks pada anak pada dasarnya merupakan upaya untuk memberikan pengetahuan tentang fungsi organ reproduksi dengan menanamkan moral etika.

Banyak orang yang mempersepsikan pendidikan seks sebagai pemberian informasi mengenai reproduksi dan hubungan seksual. Pendidikan seks sebenarnya tidak hanya itu. Haffner (1990) menyatakan bahwa pendidikan seksualitas yang komprehensif meliputi dimensi biologis, sosiokultural, psikologis, dan spiritual termasuk mengajarkan seseorang agar mampu melakukan proteksi diri dan membuat keputusan yang bertanggung jawab.

Berdasarkan fenomena tersebut, peneliti tertarik membuat program pendidikan seks pada anak usia dini yang memang dibutuhkan saat ini. Informasi mengenai seksualitas kepada kelompok anak ini dinilai akan lebih bermanfaat bila dikemas dalam bentuk sistematis. Dengan mempertimbangkan kerentanan anak menjadi korban eksploitasi seksual, program yang disusun ini akan lebih menekankan pada upaya meningkatkan keterampilan melakukan proteksi diri terhadap eksploitasi seksual. Hal ini sesuai dengan pandangan WHO yang menyatakan, bahwa anak-anak dan perempuan berada dalam kondisi kesehatan reproduksi yang kurang menguntungkan dan karena itu disepakati untuk mendapatkan prioritas penanganan.

Program pendidikan seksual ini dirancang khusus untuk anak usia dini dengan lebih mengedepankan metode yang lebih bersifat operasional dan konkret. Melalui program ini anak usia dini diprediksikan akan mampu mempelajari cara-cara untuk melindungi diri dari ancaman eksploitasi seksual secara mandiri agar nantinya dapat menjalani kehidupannya dengan baik.

Lebih jauh lagi peneliti ingin mengetahui efektivitas penerapannya pada anak usia dini sebagai bagian dari upaya untuk proteksi diri anak dari eksploitasi seksual. Program ini merupakan upaya preventif yang akan diberikan pada anak usia dini sehingga anak akan dapat terhindar dari perilaku yang tidak diinginkan yang mengarah pada kontak seksual.

Penelitian ini bertujuan untuk mengetahui kemampuan proteksi seksual pada anak dari eksploitasi seksual antara sebelum dan sesudah mendapatkan program pendidikan seksual.

\section{METODE PENELITIAN}

\section{Metode}

Metode yang dipakai dalam penelitian ini adalah metode kuasi eksperimen. Desain eksperimen yang digunakan nonrandomized pre-test dan post-test group design, yaitu pengukuran yang dilakukan sebelum perlakuan (pre-test) dan pengukuran segera setelah perlakuan selesai diberikan (post-test). Bagan desain penelitiannya tertera pada tabel 1 .

Tabel 1. Desain Penelitian

\begin{tabular}{|ccc|c|}
\hline O1 & $X$ & O2 & KE \\
\hline O1 & $\sim \mathrm{X}$ & O2 & KK \\
\hline
\end{tabular}

Keterangan :

$\begin{array}{ll}\mathrm{O} 1 & \text { : Pengukuran pre-test } \\ \mathrm{O} 2 & \text { : Pengukuran post-test } \\ \mathrm{X} & \text { : Perlakuan (Program Pendidikan Seks) } \\ \sim \mathrm{X} & : \text { Tidak diberikan perlakuan (kelompok kon- } \\ & \text { trol) } \\ \mathrm{KE} & : \text { Kelompok eksperimen } \\ \mathrm{KK} & : \text { Kelompok kontrol }\end{array}$

\section{Hipotesis}

Hipotesis dalam penelitian ini, bahwa ada perbedaan proteksi diri dari eksploitasi seksual pada anak

Perspektif Ilmu Pendidikan - Vol. 25 Th. XVI April 2012 
usia dini antara sebelum dan sesudah mendapatkan program pendidikan seks.

\section{Subjek}

Subjek dalam penelitian ini adalah anak-anak di Taman Kanak-Kanak (TK) Ar-Rahman Kuningan Jakarta Selatan. Pada penelitian ini peneliti menggunakan dua kelas yaitu kelas B1 sebagai kelompok eksperimen dan kelas B2 sebagai kelompok kontrol.

\section{Program Intervensi Psikologis}

Program pendidikan seksual pada anak usia dini ini merupakan program yang terdiri dari beberapa keterampilan psikologis yang akan diberikan antara lain kemampuan mengenali bagian tubuhnya, kemampuan mengenali situasi-situasi yang mengarah kepada eksploitasi seksual dan kemampuan untuk mengambil keputusan terhadap situasi yang mengarah kepada eksploitasi seksual tersebut. Program pendidikan seksual ini akan dikemas dalam bentuk yang menarik dengan metode permainan, role-playing, simulasi, tayangan gambar atau film. Berbagai metode ini digunakan untuk membantu memudahkan proses pemahaman anak terhadap materi pelatihan yang akan diberikan. Materi-materi dalam program pendidikan seksual pada anak usia dini, meliputi materi mengenai perkembangan anak khususnya berkaitan dengan perkembangan seksual anak, identifikasi situasi-situasi yang mengarah pada tendensi eksploitasi seksual, serta prevensi diri dari eksploitasi seksual.

Materi pertama mengenai perkembangan anak khususnya berkaitan dengan perkembangan seksual anak, yaitu upaya pengenalan bagian-bagian tubuh dengan mengidentifikasikan bagian-bagian tubuh dan mengenali perbedaan anggota tubuh antara anak jenis kelamin laki-laki dan perempuan.

Materi kedua mengenai identifikasi situasisituasi yang mengarah pada tendensi eksploitasi seksual, yaitu upaya mengenali situasi-situasi yang mengarah pada tendensi eksploitasi seksual antara lain perilaku menggoda, memegang bagian tubuh, mengintip bagian tubuh orang lain, membuka pakaian, dan memegang bagian kelamin.

Materi ketiga mengenai prevensi diri dari eksploitasi seksual bagian A, yaitu upaya mengenali dan menghindari perilaku eksploitasi seksual berkaitan dengan beberapa keadaan antara lain upaya prevensi dengan memperhatikan cara berpakaian untuk anak laki-laki dan perempuan, serta prevensi pada saat berdesakan dengan banyak orang.

Selanjutnya, materi keempat mengenai prevensi diri dari eksploitasi seksual bagian B, yaitu upaya mengenali dan menghindari perilaku eksploitasi seksual dengan melakukan beberapa cara untuk menolak tawaran, bujukan, atau paksaan dari orang lain yang membuatnya merasa takut atau tidak nyaman yang mengarah pada tindakan eksploitasi seksual.

\section{Alat Ukur yang Digunakan}

Alat ukur yang digunakan dalam penelitian ini merupakan modifikasi dari penelitian lainnya yang relevan dilakukan oleh Hastuti (2005), yaitu skala proteksi seksual dari eksploitasi seksual. Peneliti memodifikasi butir-butir yang digunakan dikaitkan dengan subjek dalam penelitian ini, yaitu anak usia dini. Instrumen ini merepresentasikan peristiwaperistiwa bertendensi eksploitasi seksual yang disertai dengan narasi singkat. Instrumen berupa butir-butir yang terdiri dari sebuah narasi singkat yang harus dijawab subjek dengan alternatif jawaban dikotomis. Alternatif jawaban yang dikotomis dipilih dengan pertimbangan, karena subjek penelitiannya adalah anak usia dini yang memiliki tingkat penyerapan dan pengolahan informasi yang terbatas, sehingga model jawaban yang mudah dan sederhana dinilai cenderung lebih sesuai. Ada tiga aspek dalam instrumen skala ini, yaitu antisipasi terhadap situasi yang mengarah pada eksploitasi seksual, kemampuan mengambil keputusan dalam situasi yang mengarah pada eksploitasi seksual, dan kemampuan bersikap asertif menghadapi eksploitasi seksual. Skala proteksi seksual pada anak usia dini ini terdiri dari 25 butir.

\section{Analisis Data}

Analisis data yang digunakan dalam penelitian ini adalah analisis kuantitatif. Analisis data kuantitatif untuk menguji hipotesis dilakukan dengan menggunakan analisis statistik berupa teknik paired sample t-test.

Perbedaan proteksi diri dari eksploitasi seksual pada anak, akibat adanya perbedaan hasil perlakuan diamati secara berulang-ulang, yaitu sebelum perlakuan dan setelah perlakuan antara kelompok eksperimen yang mendapatkan program pelatihan pendidikan seksual dengan kelompok kontrol.

\section{Prosedur}

Prosedur penelitian ini terdiri dari dua tahapan, yaitu persiapan penelitian dan pelaksanaan penelitian. a. Persiapan Penelitian

Peneliti melakukan proses penyusunan modul program pendidikan seksual. Peneliti melakukan modifikasi skala proteksi diri dari eksploitasi seksual dari penelitian sebelumnya yang dikembangkan oleh Hastuti (2005). Butir yang dituliskan lebih disesuaikan dengan konteks kasus eksploitasi seksual yang seringkali dialami atau dikabarkan dalam media-media selama ini yang terjadi pada anak. 
Peneliti lebih mengarahkan konteksnya pada proteksi diri dari eksploitasi seksual pada anak usia dini. Instrumen penelitian ini terdiri dari 25 butir. Peneliti kemudian melakukan koordinasi lebih lanjut dengan pihak TK Ar-Rahman Kuningan Jakarta Selatan untuk penentuan jadwal penerapan program pelatihan pendidikan seksual.

b. Pelaksanaan Penelitian

Setelah selesai seluruh persiapan penelitian, tahap selanjutnya adalah pelaksanaan program pendidikan seksual. Program ini dilakukan dalam bentuk yang menarik dengan metode permainan, role-playing, simulasi, tayangan gambar atau film.

Program pelatihan pendidikan seksual dilaksanakan sebanyak 4 sesi dalam waktu 4 hari selama masing-masing sesi selama 1 jam, sehingga total waktu yang diperlukan adalah 4 jam. Program pelatihan pendidikan seksual dilaksanakan pada tanggal 23 November dan 28-30 November 2011.

Peneliti melakukan koordinasi dengan pihak TK dan menentukan dua kelas sebagai subjek penelitiannya. Kelas B1 sebagai kelompok kontrol dan kelas B2 se-bagai kelompok eksperimen dalam penelitian. Pada proses awal, dengan membagikan skala proteksi seksual kepada para partisipan baik kelompok eksperimen maupun kelompok kontrol (sebagai data pre-test).

Setelah proses empat sesi program pendidikan seksual selesai dilakukan pada kelompok eksperimen, partisipan langsung diberikan post-test dengan memberikan skala proteksi seksual kembali. Pada kelompok kontrol juga dilakukan post-test dengan memberikan skala proteksi seksual tanpa diberikan perlakuan sebelumnya. Proses ini dilakukan untuk melihat efektivitas pemberian program pendidikan seksual pada anak usia dini.

\section{HASIL DAN PEMBAHASAN}

\section{Deskripsi Subjek}

Subjek penelitian yang terbagi dalam kelompok eksperimen dan kelompok kontrol ditinjau dari jenis kelamin dan usia terdapat pada tabel 2.

Tabel 2. Deskripsi Subjek Penelitian Berdasarkan Jenis Kelamin dan Usia

\begin{tabular}{|l|c|c|c|}
\hline \multirow{2}{*}{ Aspek } & \multicolumn{2}{|c|}{ Kelompok } & \multirow{2}{*}{ Jumlah } \\
\cline { 2 - 3 } & Eksperimen & Kontrol & \\
\hline Jenis Kelamin & & & \\
\hline - Laki-laki & 9 & 7 & 16 \\
\hline - Perempuan & 5 & 5 & 10 \\
\hline Usia & & & \\
\hline - 5 tahun & 9 & 11 & 20 \\
\hline - 6 tahun & 3 & 3 & 6 \\
\hline
\end{tabular}

\section{Hasil Analisis Uji Hipotesis}

Hasil analisis data antara kelompok yang mendapatkan perlakuan (kelompok eksperimen) dan kelompok yang tidak mendapatkan perlakuan (kelompok kontrol) pada kondisi awal pengukuran sebelumnya (pre-test) menemukan yaitu $\mathrm{t}=0,247, \mathrm{p}=$ $0,809>0,05$ (tidak signifikan). Artinya, tidak ada perbedaan pada kondisi awal sebelum pengukuran (pre-test) antara kelompok eksperimen dan kelompok kontrol.

Hasil analisis data selanjutnya dengan menggunakan paired sample t-test antara kelompok yang tidak mendapatkan perlakuan (kelompok kontrol) pada pengukuran sebelum (pre-test) dan sesudahnya (post-test) menemukan yaitu $\mathrm{t}=1,915, \mathrm{p}=0,082>0,05$ (tidak signifikan). Artinya, tidak ada perbedaan yang signifikan pada kelompok kontrol antara sebelum dan sesudahnya.

Hasil analisis antara kelompok eksperimen yang mendapatkan perlakuan pada pengukuran sebelum (pre-test) dan sesudah perlakuan (post-test) menemukan yaitu $t=5,548, p=0,000<0,05$ (signifikan). Artinya, ada perbedaan yang signifikan pada kelompok eksperimen antara sebelum dan sesudah perlakuan diberikan.

Selanjutnya untuk melihat perbedaan skor proteksi diri tersebut, rata-rata skor proteksi diri pada pengukuran kelompok eksperimen terlihat pada tabel 3 .

Tabel 3. Perbedaan Rata-rata Skor Proteksi Diri Pada Kelompok Eksperimen

\begin{tabular}{|c|c|}
\hline Pengukuran & Rata-Rata \\
\hline Pre-test & 7,79 \\
\hline Post-test & 11,36 \\
\hline
\end{tabular}

Dari tabel di atas menunjukkan, bahwa pada kelompok eksperimen terjadi peningkatan skor ratarata proteksi diri pada pengukuran antara sebelum (pre-test) dan sesudah (post-test) program pendidikan seksual. Rerata peningkatan proteksi diri tersebut sebesar 3,57.

Berdasarkan hasil analisis tersebut dapat disimpulkan, bahwa hipotesis yang diajukan dalam penelitian ini dapat diterima. Ada perbedaan proteksi diri yang signifikan pada anak usia dini antara sebelum dan sesudah mendapatkan program pendidikan seksual.

\section{Pembahasan}

Hasil yang diperoleh dalam penelitian ini menunjukkan bahwa ada perbedaan proteksi diri yang signifikan pada anak usia dini antara sebelum dan sesudah mendapatkan program pendidikan 
seksual. Analisis statistik antara kelompok eksperimen yang mendapatkan perlakuan pada pengukuran sebelum (pre-test) dan sesudah perlakuan (post-test) menemukan yaitu $\mathrm{t}=5,548, \mathrm{p}=0,000<0,05$ (signifikan). Artinya, ada perbedaan yang signifikan pada kelompok eksperimen antara sebelum dan sesudah perlakuan diberikan. Pada kelompok eksperimen terjadi peningkatan skor rata-rata proteksi diri pada pengukuran antara sebelum (pre-test) dan sesudah (post-test) program pendidikan seksual dengan rerata peningkatan skor proteksi diri sebesar 3,57.

Ada beberapa faktor yang mendukung peningkatan kemampuan proteksi diri pada anak, yaitu metode pembelajaran, materi yang diberikan, dan kualitas fasilitator. Metode yang digunakan selama pelaksanaan program pendidikan seksual menggunakan simulasi dengan alat bantu visual dan roleplaying. Penelitian yang dilakukan oleh Maurer (2001), menyatakan perlunya alat bantu visual, pengulangan kata kunci, penyampaian materi secara simpel, humor, banyak permainan (games) yang dilakukan serta keterlibatan seluruh unsur kognitif, afektif, dan psikomotorik. Misalnya, materi-materi pada sesi ketiga dan keempat para subjek diminta untuk mempraktikkan secara langsung dengan melibatkan semua unsur baik kognitif, afektif, maupun psikomotorik untuk mencoba berlatih sikap dan tindakan tertentu untuk menghindari dari perilaku eksploitasi seksual pada anak usia dini.

Teknik simulasi dengan menggunakan alat peraga dan role-playing tersebut, mendekatkan jarak hal-hal abstrak sekitar materi pada realitas keadaan yang lebih nyata. Hal ini sesuai dengan karakteristik tahap perkembangan kognitif pada masa anak-anak yang mulai belajar mengatasi masalah secara konkret. Proses belajar ini merupakan fungsi interaksi antara anak dengan lingkungan di luar dirinya yang lebih terlatih (dalam hal ini trainer dan co-trainer), sehingga dengan bantuan dari pihak luar ini akan sangat dapat membantu dirinya.

Relevansi dengan realitas juga diartikan dengan cara pemberian materi yang berupaya sedekat mungkin dengan keadaan realitas keadaan subjek termasuk pemberian contoh dan penggunaan bahasa. Materi disajikan dengan banyak memberikan contoh pada bagian-bagian penting dan fasilitator sering mengulangi kata-kata kunci kepada para partisipan penelitian seperti "bilang TIDAK", "LARI".

Keberhasilan pelatihan yang telah dicapai dalam penelitian ini, mendukung beberapa penelitian yang menunjukkan adanya pengaruh positif program pendidikan seksual sebagai upaya preventif proteksi diri dari eksploitasi seksual pada anak usia dini. Penelitian yang dilakukan oleh Haffner (1990) menyatakan, bahwa pendidikan seksualitas yang komprehensif meliputi dimensi biologis, sosiokultural, psikologis, dan spiritual termasuk mengajarkan seseorang agar mampu melakukan proteksi diri dan membuat keputusan yang bertanggung jawab adalah sangat penting diterapkan pada anak.

\section{Implikasi}

Salah satu upaya untuk meningkatkan kemampuan proteksi diri dari eksploitasi seksual pada anak usia dini adalah dengan memberikan program pendidikan seks. Hasil penelitian ini menunjukkan, bahwa program pendidikan seks efektif dapat meningkatkan kemampuan proteksi diri dari eksploitasi seksual pada anak usia dini. Program seks dapat diterapkan dan menjadi bagian dari sekolah. Sekolah dapat mempersiapkan dan mensinergikan program ini dengan proses pembelajaran dan kebijakan yang telah ditetapkan di sekolah tersebut.

Program seks terdiri dari berbagai pengetahuan dan keterampilan yang diberikan sebagai bagian upaya proteksi diri anak dari perilaku eksploitasi seksual. Program ini dapat menjadi bagian dari program yang terdapat pada kurikulum sekolah. Materi yang diberikan pada program ini dapat disinergikan dengan materi-materi lainnya pada anak. Hal ini harus diperkenalkan kepada anak sejak awal sehingga dapat menjadi upaya preventif dalam mengatasi kecenderungan terjadinya perilaku eksploitasi seksual pada anak.

\section{PENUTUP}

\section{Kesimpulan}

Hasil dari penelitian ini menunjukkan, bahwa ada perbedaan proteksi diri yang signifikan pada anak usia dini antara sebelum dan sesudah mendapatkan program pendidikan seksual.

\section{Saran}

Berdasarkan hasil yang diperoleh dari penelitian ini, peneliti mencoba membuat beberapa saran kepada beberapa pihak, yaitu pihak sekolah (Taman Kanak-Kanak), subjek penelitian, dan untuk peneliti selanjutnya.

Untuk pihak sekolah, program pendidikan seksual ini dapat dijadikan sebagai salah satu program preventif untuk meningkatkan proteksi diri dari eksploitasi seksual pada anak nantinya. Pihak sekolah diharapkan dapat menjadikan program ini sebagai bagian dari school-based intervention dan dapat 
memperluas kebermanfaatan program ini bagi para siswa-siswa lainnya. Hal lainnya juga, pihak sekolah dapat mempertimbangkan untuk menjadikan program pendidikan seksual ini sebagai bagian dari kurikulum pembelajaran di sekolah. Tujuan akhirnya dapat membantu mengatasi perilaku eksploitasi seksual pada anak-anak.

Saran yang diberikan kepada subjek penelitian diharapkan subjek penelitian tetap dapat terus mempraktikkan latihan-latihan dari materi program yang telah didapatkan dalam kehidupannya sehari-hari.

Ada beberapa hal yang dapat dipertimbangkan untuk peneliti selanjutnya yang tertarik untuk mengembangkan penelitian ini antara lain dalam hal teknik pengambilan subjek pada penelitian mendatang sebaiknya menggunakan teknik purposive sampling (misalnya individu-individu yang memiliki skor proteksi diri yang rendah) sehingga anak-anak yang hanya memiliki karakteristik tertentu itu yang memiliki kesempatan untuk menjadi partisipan penelitian. Dengan demikian, perlakuan yang diberikan dinilai dapat lebih tepat pada sasarannya. Proses program pendidikan seksual ini juga sebaiknya diberikan dalam jangka waktu yang agak lebih lama sehingga para subjek penelitian memiliki kesempatan untuk melakukan atau mentransfer terlebih dahulu materimateri yang didapatkan dari pelatihan dalam kehidupan sehari-harinya. Untuk penelitian mendatang sebaiknya juga mengikutsertakan proses pengukuran tindak lanjut (follow-up) sehingga peneliti tetap dapat melihat keberlangsungan efek program pendidikan seksual ini dalam waktu beberapa minggu atau beberapa bulan setelah program selesai dilakukan. Alat ukur yang digunakan dalam penelitian ini sebaiknya menggunakan kartu bergambar disertai dengan narasi dalam penjelasan kepada subjek penelitiannya. Hal ini dilakukan dengan mempertimbangkan karakteristik perkembangan anak, sehingga pada akhirnya akan dapat mempercepat dan membantu proses pengumpulan datanya. Anak sebagai partisipan penelitian juga dapat memahami item yang diberikan dalam kartu tersebut dengan lebih jelas dan baik.

\section{DAFTAR PUSTAKA}

Haffner, D.W. (1990). Sex education: A call to action. New York: Sex Information and Education of US Hastuti, L.W. (2005). Efektivitas pendidikan seksualitas bagi remaja educable mentally retarded untuk meningkatkan proteksi diri dari eksploitasi seksual. Thesis. Tidak Diterbitkan. Yogyakarta: Program Pascasarjana Fakultas Psikologi Universitas Gadjah Mada.

Kurniati, T., Rahmat, I., \& Lusmilasari, L. (2005). Hubungan antara persepsi ibu tentang pendidikan seks pada anak usia 0-15 tahun dengan sikap ibu dalam menerapkan pendidikan seks. Jurnal Kebidanan dan Keperawatan Aisyiyah, Vol 1, Nomor 1.

Sumartono, S., \& Intasari, I. (2008). Program "Aku \& Kamu". Jakarta: Tudung Saji.

Korban pelecehan seksual sebagian besar anak. Diakses tanggal 12 Oktober 2010 dari situs www.Antaranews.com.

Kekerasan seksual terhadap anak naik signifikan. Diakses tanggal 12 Oktober 2010 dari situs www. Republika.co.id. 